\title{
Path Analysis on Factors Affecting Job Performance of Midwives at Community Health Centers in Mojokerto, East Java
}

\author{
Veterina Rizki Amalia'), Hanung Prasetya'), Bhisma Murti1) \\ 1)Masters Program in Public Health, Universitas Sebelas Maret \\ ${ }^{2}$ Study Program in Acupuncture, Health Polytechnics, Ministry of Health Surakarta
}

\section{ABSTRACT}

Background: Midwives play an important role in reducing maternal and neonatal morbidity and mortality. The performance of midwives is an important indicator to improve the quality of maternal and child health services. The purpose of this study was to analyze the factors that affect the performance of midwives. Subjects and Method: This cross-sectional study was conducted at a community health center in Mojokerto, East Java, from February to April 2020. A sample of 200 midwives was selected by random sampling. The dependent variable was the performance of the midwife. The independent variables were age, income, workload, work motivation, perceived financial compensation, education, employment status, social support, and marital status. The performance of midwives was measured by the 6DSNP. Other data were collected using a questionnaire. Data were analyzed by path analysis using the Stata 13 application.

Results:The performance of midwives increased with age $\geq 42$ years $(b=3.19 ; 95 \% \mathrm{CI}=1.62$ to $4.75 ; \mathrm{p}<0.001$ ), family income $\geq 7$ million $(b=3.03 ; 95 \% \mathrm{CI}=1.50$ to $4.56 ; \mathrm{p}<0.001)$, light workload $(\mathrm{b}=2.66 ; 95 \% \mathrm{CI}=1.19$ to 4.13 ; $\mathrm{p}$ <0.001), strong work motivation ( $\mathrm{b}=3.32$; $95 \%$ $\mathrm{CI}=1.60$ to $5.04 ; \mathrm{p}<0.001$ ), sufficient perceived financial compensation $(b=3.96 ; 95 \%$ $\mathrm{CI}=1.68$ to $4.99 ; \mathrm{p}<0.001)$. The performance of midwives was indirectly affected by education, employment status, social support and marital status.

Conclusion: Age, family income, workload, work motivation, and perceived financial compensation affect the performance of midwives.

Keywords: performance, midwives, path analysis

\section{Correspondence:}

Veterina Rizki Amalia. Masters Program in Public Health, Universitas Sebelas Maret.Jl. Ir. Sutami 36A, Surakarta 57126, Central Java. Email: veterinarizki1@gmail.com. Mobile: +6281359016501 .

Cite this as:

Amalia VR, Prasetya H, Murti B (2021). Path Analysis on Factors Affecting Job Performance of Midwives at Community Health Centers in Mojokerto, East Java. J Health Policy Manage. 06(01): 21-34. https://doi.org/10.26911/thejhpm.2021.06.01.03.

cc (i) (2) Journal of Health Policy and Management is licensed under a Creative Commons Attribution-NonCommercial-ShareAlike 4.0 International License.

\section{BACKGROUND}

Sustainable Development Goals (SDGs) are a plan for a global movement approved by world leaders, including Indonesia, to alleviate poverty, reduce inequality, and protect the environment. The third goal of the SDGs is to ensure a healthy life and support all ages' wellbeing. The SDGs target in maternal and child health is by 2030 to reduce the maternal mortality rate (MMR) to 70 per 100,00o live births (SDGs, 2019).

Based on the 2015 Inter-Census Population Survey (SUPAS) results, the MMR in Indonesia is 305 per 100,000 live births. This figure does not achieve the MDGs target that must be achieved, namely 102 per 100,000 live births. In 2017, the MMR of East Java Province reached 91.92 per 100,000 live births. The highest MMR in 
2017 in East Java Province was in Mojokerto, namely 171.88 per 100,000 live births or maternal deaths in 2017 in Mojokerto as many as 29 people (East Java Provincial Health Office, 2017).

Health professionals play an important role in improving access and quality of health services for the community (Gedif et al., 2018). Midwives play an important role in reducing maternal and neonatal morbidity and mortality and the key to achieving MDG 4 and MDG 5, which are now SDGs 3 (Bekru et al., 2017).

The quality of performance of midwives is important to improve maternal and child health services. Successful maternal health services must have good midwifery performance in providing pregnancy, childbirth and postpartum services (Alkasseh and Kweik, 2019). Performance is the level of success of a person in his job judged by comparing the success rate of a person's behavior with organizational expectations (Kalhor et al., 2018).

A study conducted by Alkasseh and Kweik (2018) on 212 midwives and nurses working in the maternity department proved that salary, availability of transporttation, marital status, age, years of service, work position (supervisor, head of room/unit, staff) affected the quality of midwife performance. Kalhor et al. (2018) conducted a study on clinical staff who work in hospitals. They found that work experience, employment status, and shift work affected performance.

Bakshi et al. (2017) found that sex and education level are related to performance. Pour et al. (2016), in their study, proved that fair and decent wages, safe workplaces, self-development, career opportunities, social integration, organizational rules and social support affect performance.

Every organization should pay more attention to employee performance and monitor it on an ongoing basis. In the field of health, human resources (HR) is an important domain. Therefore, it is necessary to conduct a study on the factors that affect the performance of midwives.

\section{SUBJECTS AND METHOD}

\section{Study Design}

This studywas an analytical observational study with a cross-sectional design. The study was conducted at a community health center in Mojokerto, East Java, from February to April 2020.

\section{Populationand Sample}

The population in this study consisted of midwives who worked at the health centers in Mojokerto. A sample of 200 midwives was selected by random sampling.

\section{Study Variables}

The dependent variable was performance. The independent variables were age, income, workload, work motivation, perceived financial compensation, education, employment status, social support and marital status.

\section{Operational Definition of Variables}

The performance was the quality and/or quantity of a midwife's work in carrying out the main tasks and functions based on standard operating procedures that apply in the organization. The instrument used was 6-DSNP. The data scale was continuous, but for data analysis, it was changed to a dichotomy, code $\mathrm{O}=$ less and $1=$ good.

Age was the length of time to live from birth. Data were collected using a questionnaire. The data scale was continuous, but for analysis, it was changed to a dichotomy, code $0<42$ years and $1 \geq 42$ years.

Family income was the average monthly income of the core family in the last 6 months. Data were collected using a questionnaire. The data scale was continuous, but for data analysis, it was changed to a 
dichotomy, code $0<7$ million and $1 \geq 7$ million.

Workloads were tasks given to midwives to be completed within a certain time. Data were collected using a questionnaire. The data scale was continuous, but for data analysis, it was changed to a dichotomy, code $\mathrm{O}=$ heavy and $1=$ light.

Work motivation was a work motivation that comes from within to do midwifery work according to the standard operating procedures. Data were collected using a questionnaire. The data scale was continuous, but for data analysis, it is changed to a dichotomy, code $0=$ weak and $1=$ strong.

Perceived financial compensation was an individual's view of the financial rewards/services received for the work performed. Data were collected using a questionnaire. The data scale was continuous, but for data analysis, it was changed to a dichotomy, code $0=$ insufficient and $1=$ sufficient. Education was the last formal education that had been undertaken by a study subject and received a certificate. Data were collected using a questionnaire. Categorical data scale, coded $\mathrm{O}=3^{\text {rd }}$ level of associate degree and $1>3^{\text {rd }}$ level of an associate degree.

Employment status was a condition that differentiates employees from one another in an organization. Data were collected using a questionnaire. Categorical data scale, coded $0=$ ASN and $1=$ non ASN .

Social support was support from the work environment. Data were collected using a questionnaire. The data scale was continuous, but for data analysis, it was changed to a dichotomy, code $\mathrm{O}=$ weak and $1=$ strong.

Marital status was a marriage bond that had been legalized by the KUA (Religious Affairs Office). Data were collected using a questionnaire. Categorical data scale, code $\mathrm{O}=$ not $\mathrm{married} /$ divorced and $1=$ married.

\section{Data Analysis \\ a. Univariate Analysis}

Univariate analysis was performed on each study variable. Categorical data were described with a frequency distribution table. A continuous sample of data characteristics were described in terms of the parameters $\mathrm{n}$, mean, SD, minimum, and maximum.

\section{b. Bivariate Analysis}

The bivariate analysis in this study used the Pearson correlation test. This test was to determine how much the correlation between the independent variable and the dependent variable.

\section{c. Multivariate Analysis}

Multivariate analysis was used to determine the effect of various variables studied using Path Analysis using the Stata 13.

\section{Research Ethic}

This study was conducted based on research ethics, namely informed consent, anonymity, confidentiality, and ethical research. Research ethics was obtained from the Health Research Ethics Committee at Dr. Moewardi, Surakarta, Indonesia, No. 124/I/ HREC/2020.

\section{RESULTS \\ 1. Univariate analysis}

Table 1 shows the sample characteristics (continuous data). Categorical data were described in Table 2. Table 2 shows that the study subjects' age was at most $\geq 42$ years old with a total of 116 people (58\%). The education level of $3 \mathrm{r}$ level associate degree was 111 people (55.5\%). Most of the study subjects worked for $\geq 18$ years, as many as 112 people (56\%). Most of the study subjects were civil servants, as many as 136 people (68\%). The study subjects were married as many as 177 people (88.5\%). Shift work system as many as 112 people (56\%). 
Table 1. Sample Characteristics (continuous data)

\begin{tabular}{lccccc}
\hline Variable & N & Min. & Max. & Mean & SD \\
\hline Performance & 200 & 80 & 120 & 103.81 & 7.44 \\
Perceived financial compensation & 200 & 9 & 18 & 14.09 & 2.56 \\
Workload & 200 & 5 & 15 & 9.78 & 2.44 \\
Social support & 200 & 8 & 15 & 13.25 & 1.95 \\
Work motivation & 200 & 10 & 18 & 15.53 & 2.29 \\
\hline
\end{tabular}

Table 2. Sample Characteristics (categorical data)

\begin{tabular}{lcc}
\hline \multicolumn{1}{c}{ Characteristics } & N & \% \\
\hline Age & 84 & 42 \\
$<42$ years & 116 & 58 \\
$\geq 42$ years & 111 & $55 \cdot 5$ \\
Education & 82 & 41 \\
$3^{\text {rd level of associate degree }}$ & 5 & 2.5 \\
$4^{\text {th level of associate degree }}$ & 2 & 1 \\
Bachelor degree & & \\
Master degree & 88 & 44 \\
Length of employment & 112 & 56 \\
$<18$ years & 136 & 58 \\
l18 years & 64 & 32 \\
Employment status & & \\
Civil servant & 177 & 88.5 \\
Non-civil servant & 10 & 5 \\
Marital Status & 13 & 6.5 \\
Married & & 56 \\
Single & 112 & 44 \\
Divorced & 88 & \\
Work system & & \\
Shift & & \\
Not shift & &
\end{tabular}

\section{The result of bivariate analysis}

Bivariate analysis was used to determine the correlation between the independent variable and the dependent variable. The results of the bivariate analysis of the effect of age, education, employment status, family income, marital status, perceived financial compensation, workload, social support, and motivation on midwife performance were presented in Table 3 .

\section{3 . The result of path analysis}

Table 4 shows that midwives' performance was directly affected by age, income, workload, motivation, and perceived financial compensation. The performance of midwives was indirectly affected by education, employment status, social support and marital status.

Table 4 shows that the performance of midwives was directly affected by age $\geq 42$ years $(b=3.19 ; 95 \% \mathrm{CI}=1.62$ to $4.75 ; \mathrm{p}=$ $<0.001$ ), family income $\geq 7$ million ( $b=$ 3.03; $95 \% \mathrm{CI}=1.50$ to 4.56 ; $\mathrm{p}<0.001$ ), light workload $(\mathrm{b}=2.66 ; 95 \% \mathrm{CI}=1.19$ to 4.1.3; $\mathrm{p}<0.001)$, strong motivation $(\mathrm{b}=3.32 ; 95 \%$ $\mathrm{CI}=1.60$ to $5.04 ; \mathrm{p}<0.001)$, perceived financial compensation $(b=3.96$; $95 \% \mathrm{CI}=$ 1.68 to $4.99 ; \mathrm{p}<0.001)$. Figure 1 shows that the performance of a midwife was indirectly affected by education, employment status, social support and marital status. 
Table 3. The results of the bivariate analysis of factors related to the performance of midwives

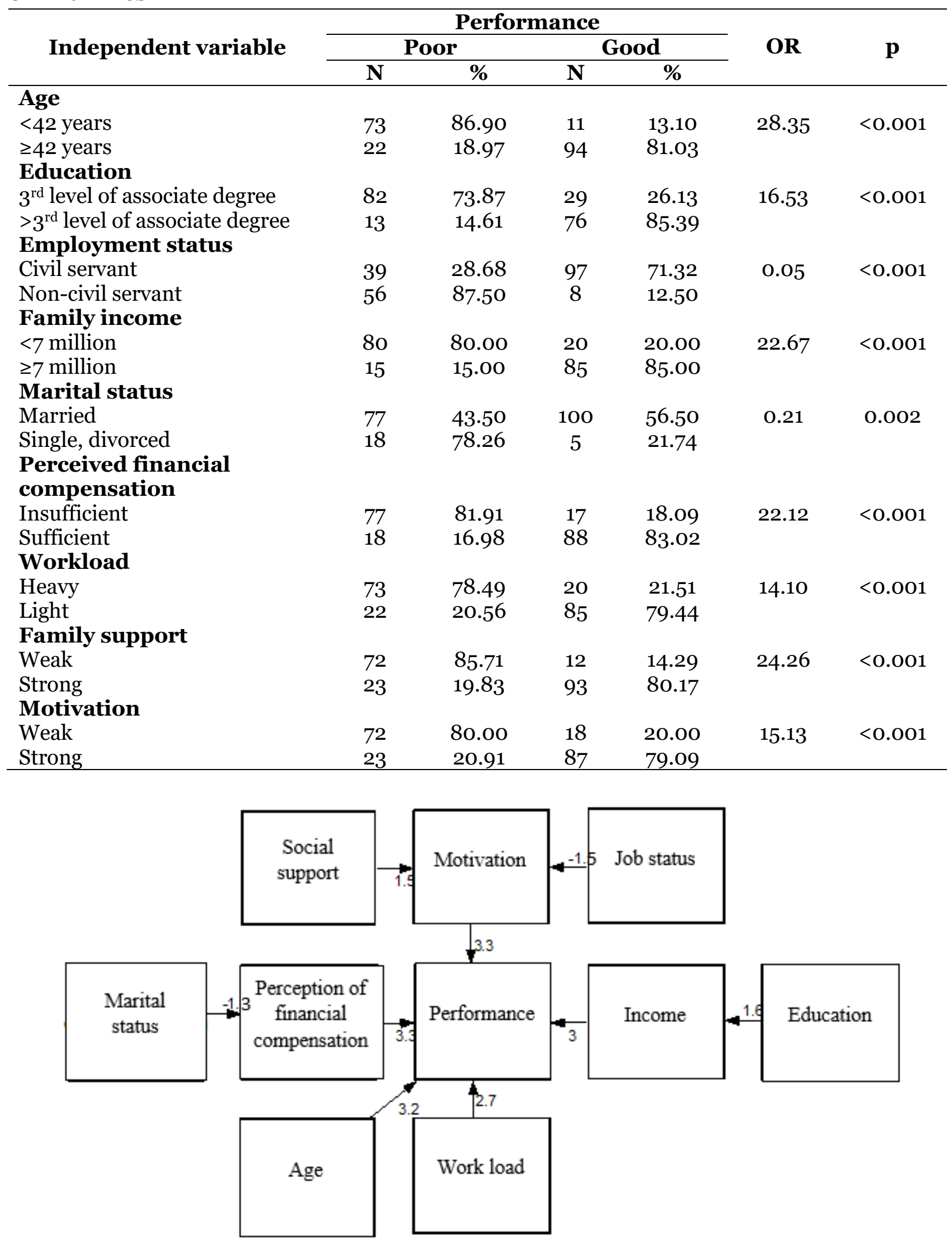

Figure 1. Path analysis model structure 
Table 4. Factors affecting the performance of midwives

\begin{tabular}{|c|c|c|c|c|c|}
\hline \multirow{2}{*}{$\begin{array}{c}\text { Variable } \\
\text { Dependent }\end{array}$} & \multirow[b]{2}{*}{ Independent Variable } & \multirow{2}{*}{$\begin{array}{c}\text { Path } \\
\text { Coefficient } \\
\text { (b) }\end{array}$} & \multicolumn{2}{|c|}{$95 \%$ CI } & \multirow[b]{2}{*}{$\mathbf{p}$} \\
\hline & & & $\begin{array}{l}\text { Lower } \\
\text { limit }\end{array}$ & $\begin{array}{l}\text { Upper } \\
\text { limit }\end{array}$ & \\
\hline \multicolumn{6}{|l|}{ Direct effect } \\
\hline \multirow{5}{*}{$\begin{array}{l}\text { Performance } \\
\text { (good) }\end{array}$} & $\leftarrow$ Age $(\geq 42$ year $)$ & 3.19 & 1.62 & 4.75 & $<0.001$ \\
\hline & $\leftarrow$ Income $(\geq 7$ million $)$ & 3.03 & 1.50 & 4.56 & $<0.001$ \\
\hline & $\leftarrow$ Workload (light) & 2.66 & 1.19 & 4.13 & $<0.001$ \\
\hline & $\leftarrow$ Motivation (strong) & $3 \cdot 32$ & 1.60 & 5.04 & $<0.001$ \\
\hline & $\begin{aligned} \leftarrow & \text { Perceived financial } \\
& \text { compensation (sufficient) }\end{aligned}$ & 3.96 & 1.68 & 4.99 & $<0.001$ \\
\hline \multicolumn{6}{|l|}{ Indirect effect } \\
\hline \multirow[t]{2}{*}{$\begin{array}{l}\text { Income } \\
\text { Motivation }\end{array}$} & $\begin{array}{l}\leftarrow \text { Education }(>3 \text { rd level } \\
\text { association degree) }\end{array}$ & 1.57 & 0.97 & 2.18 & $<0.001$ \\
\hline & $\begin{array}{l}\leftarrow \text { Employment status (non- } \\
\text { civil servant) }\end{array}$ & -1.54 & -2.25 & -0.82 & $<0.001$ \\
\hline Perceived & $\leftarrow$ Social support (strong) & 1.5 & 0.88 & 2.20 & $<0.001$ \\
\hline financial status & $\begin{array}{l}\leftarrow \text { Employment status } \\
\quad \text { single, divorced) }\end{array}$ & -1.30 & -2.28 & -0.33 & 0.009 \\
\hline \multicolumn{6}{|c|}{$\mathrm{N}$ observation $=\mathbf{2 0 0}$} \\
\hline \multicolumn{6}{|c|}{$\mathrm{AIC}=821.27$} \\
\hline $\mathrm{BIC}=864.15$ & & & & & \\
\hline
\end{tabular}

DISCUSSION

\section{The Effect of Age on Performance}

This study indicated that there was a correlation between age and performance. Midwives over 42 years of age were 3.19 times more likely to perform well than those younger than 42 years $(b=3.19 ; C I=1.62$ to 4.75; $\mathrm{p}<0.001$ ).

Gusti et al. (2018) stated that age had a significant effect on the performance of midwives. Midwives of older age $(\geq 27$ years) were likely to perform better than younger midwives. In some of the literature on performance, there is a tendency to combine age and experience.A lot of work experience with increasing age so that performance increases. Age increases along with more work experience so that performance increases (Kooji et al., 2013).

Over the past 40 years, researchers have examined age stereotypes in the workplace. Some of the stereotypes about older workers are that they are less creative, less flexible, more resistant to change, and not interested in training (Bertolino et al.,
2013). This is confirmed by a study conducted by Rahmadani et al. (2019), which stated that age affected midwives' performance. Age over 45 years has the potential to reduce performance. The study conducted by Cahyandaru et al. (2019) on surveillance officers found that age affects performance. Older surveillance officers ( $\geq 25$ years) have the potential to reduce performance.

Negative stereotypes about older workers are inconsistent with their actual performance. Their performance may be similar or even higher than that of younger workers (e.g., safety, behavior as a member of the organization). Stereotypes about older workers are not always negative. Older workers are perceived to be more positive than younger workers in terms of stability, commitment and job satisfaction (Bertolino et al., 2013).

\section{The effect of income on perfor- mance}

The results of this study indicated that there was a correlation between income and performance. Midwives with higher income 
were 3.03 times more likely to perform well than those with low income $(b=3.03 ; 95 \%$ $\mathrm{CI}=1.50$ to 4.56 ; $\mathrm{p}<0.001$ ).

This is in accordance with a study conducted by Adam and Wirdawaty (2015) on midwives at Prof. General Hospital. Dr. H. AloeiSaboe shows that income and motivation affect performance. Economic problems are one of the factors preventing quality midwifery services. The economic problems in question are low or no midwife wages, informal payments and lack of goverment financial commitment (Filby et al., 2016).

Barriers to delivering quality midwifery services in poor and developing countries are social, cultural, and human resource barriers. Barriers in terms of human resources can be viewed from the lack of health workers or the uneven distribution of health personnel (Filby et al., 2016). The lack of midwives' availability can be linked to low salaries, requiring midwives to develop private practices. A study conducted by Ensor et al. (2008) found that more than two-thirds of midwives' income came from private practice. More than 90\% of midwives generated income this way. This condition causes midwives to prefer clients who can pay for services directly. They do not practice in rural areas because it is more difficult to earn income from private practice (D'Ambruoso et al., 2010).

Income from private practice is closely related to competence and experience. Income is largely determined by experience rather than performance (Ensor et al., 2008). Data from Afghanistan, Indonesia, Anambra, Nigeria, Uganda, Koutiala, Mali across African and poor-developing countries collectively reveal that many midwives survive on salaries that cannot meet basic living costs. These salaries are rarely paid or are not paid at all (Filby et al., 2016). In Senegal, inadequate income is associated with low motivation, selfesteem, satisfaction, and midwives (Rouleau et al., 2012).

\section{The effect of workload on perfor- mance}

The results of this study indicated that there was a correlation between workload and performance. Midwives with light workloads could perform well 2.66 times greater than those with heavy workloads $(b=2.66 ; 95 \% \mathrm{CI}=1.19$ to 4.13 ; $\mathrm{p}<0.001$ ).

High workload contributes to the onset of fatigue, illness and other problems, leading to decreased performance (Fan and Smith, 2017). The results of a study conducted by Asmani et al. (2015) which found that interruptions in the work, procedures and processes of serving clients are a significant determinant of the workload of health workers in their study subjects. The workload level significantly impacts performance. An increasing workload will reduce the performance of health workers.

High workload and fatigue result in decreased performance in daily work. Workload and fatigue are associated with decreesed performance. The high workload is one factor that causes fatigue and subsequently results in decreased performance (Fan and Smith, 2017).

Through their study, Shah et al. (2011) found that too high workload and too low workload correlate with low performance (Asamani et al., 2015). Besides, Shah et al. (2011) and Musau et al. (2008) argue that a sudden increase or decrease in workload causes a decrease in performance. Still, a sudden increase in the workload curve is more sensitive and can have a negative impact on performance employees (Asamani et al., 2015).

Employees must be competent, have a comfortable and safe work environment, and an appropriate workload and adequate facilities to ensure good employee perfor- 
mance (Asamani et al., 2015). Regular exercise and physical exercise are effective strategies to reduce workload. Reduced workload will improve employee performance. Therefore, physical fitness is important for employees (Weyh et al., 2020).

\section{The effect of motivation on perfor- mance}

The results of this study indicated a correlation between motivation and performance. Midwives with strong motivation had the possibility to perform well 3.32 times greater than midwives with weak motivation $(\mathrm{b}=3.32 ; 95 \% \mathrm{CI}=1.60$ to $5.04 ; \mathrm{p}$ $<0.001)$.

Qualified and highly motivated human resources are essential for health services (Asamani et al., 2015). Work motivation is very important for the performance of health workers (Bhatnagar et al., 2017). In health organizations, work motivation is an important measure of health workers' response to increasing challenges and demands (Baljoon et al., 2018). Motivation is an important behavior that affects individual performance at work. Individuals without motivation will easily get bored or lose interest in doing tasks and increase the likelihood that they will stop working (Sarwar and Khalid, 2015).

Several studies conducted in health care settings have found that motivation affects performance and outcomes in health care. A study on nurses who work in private hospitals in Malaysia proves that motivation is positively related to performance (Hee et al., 2016). Motivation has a positive effect on midwives' performance in preeclampsia management in Malang, East Java (Jayanti et al., 2017).

The work motivation of nurses and midwives impacts welfare, organizational performance, satisfaction, and commitment (Toode et al., 2015). Promoting employee motivation in the workplace is very impor- tant because motivation will lead to positive results for the organization (Galletta et al., 2016).

Low work motivation accompanied by job dissatisfaction can cause individuals to fail to apply knowledge and skills at work and reduce health services quality (Negarandeh et al., 2015). Further studies in Canada of nurses and midwives show that motivation is negatively related to fatigue and positively related to commitment and performance (Fernet et al., 2015).

\section{The effect of perceived financial compensation on performance}

The results of this study indicated that there was a correlation between perceived financial compensation on performance. Midwives with a perceived financial compensation were sufficient were 3.96 times more likely to perform well than midwives with the perception that financial compensation was insufficient $(b=3.96 ; 95 \% \mathrm{CI}=$ 1.68 to $4.99 ; \mathrm{p}<0.001$ ).

Perception is full of meaning. Employees' perceived financial compensation are influenced by several factors, namely information on coworkers' salaries, information on salaries in the area, comparisons with salaries of colleagues from the same company and other companies, and the cost of living in the area (Hammami, 2020). Ockenfels et al. (2015), in their study, proved that employees with low salaries are not satisfied with their work. There is a decrease in performance when they find out that their salaries are not comparable.

Salary reality is different from employee salary perception. A study conducted by Hammami et al. (2020) found that financial auditors' performance is affected by future career opportunities rather than current salaries.

Employees' perceptions about compensation affect employees' attitudes toward employers and their commitment to 
the organization. Employees expect fairness when compensated for work completed and may become dissatisfied. Therefore, employers can reduce employee work or seek change/improvement whenever they feel that their work is not rewarded (Agwu, 2013).

Compensation is an important factor in job satisfaction theory. Perceptions of justice in the compensation system are positively related to the three dimensions of justice. Three dimensions of justice are performance-based distributive justice, comparative distributive justice relative to foreign workers, and comparative distributive justice to local colleagues. In particular, the compensation system's fairness is more closely related to performance-based distributive justice than the two dimensions of distributive justice based on social comparisons (Shooshtarian et al., 2013).

Employees expect "fairness," i.e., compensation that is proportional to their contribution from the employer. A study conducted by Agwu (2013) found that a fair compensation system affects employee performance. Perceived fairness of compensation impacts employee and organizational performance such as absence, individual work, and organizational work. People perform well according to what they perceive to be fair compensation. Employees consider whether management has treated them fairly. They see what they receive for the effort they have put in compared to colleagues. If the compensation received is compared to coworkers, employees will feel satisfied and improve their performance.

\section{Indirect Effect on Performance}

\section{a. The Effect of Education on Income}

The results of this study indicated that there was an indirect effect of education on the performance of midwives through income.
This is in accordance with Stryzhak's (2020) study, which found that education is closely related to income levels, economic independence, and happiness. Education not only contributes to increasing income but also makes people happier. Higher education is very important to improve skills and knowledge in providing midwifery services. Higher education, income, and support systems are the main strategies for improving midwifery services' performance and quality (Khosravy et al., 2020).

\section{b. The Effect of Employment Status on Motivation}

The results of this study indicated that there was an indirect effect of employment status on the performance of midwives through motivation.

This is according to Ogunleye and Osekita (2016), which found a significant influence between employment status and motivation. The results also show that employment status, together with motivation, affects performance. This proves that the midwife or employee is eager to improve their employment status. Work and income affect social status. This is what motivates midwives or employees to improve performance (Bahadori et al., 2013). The head nurse (the nurse's position as leader) is more motivated than the staff nurse. Employment status and authority are the most important factors contributing to work motivation (Baljoon et al., 2018).

\section{c. The Effect of Social Support on Motivation}

The results of this study indicated that there was an indirect effect of social support on the performance of midwives through motivation.

Social support can be defined in various ways, such as social support, seen as the number of social contacts by a person or social network. Lack of social support (for example, direct support from superiors and 
colleagues) can increase nurses or midwives' risk of moving to other workplaces (Heijden et al., 2010). Social support and independence in job scheduling are significant factors of motivation and satisfaction in the workplace (Galletta et al., 2016).

The work environment is an important factor in the nurse and midwife profession (Heijden et al., 2010). A work environment that is supportive and able to meet employees' basic needs and psychological needs such as appreciation, approval, and competence will increase motivational behavior and encourage positive attitudes such as commitment and satisfaction at work (Galletta et al., 2016). Employees who feel supported by the organization will respond with a positive work attitude and a low desire to change jobs (Beheshtifar et al., 2012).

Mutual supportive relationships and effective communication in the workplace are linked to increased work motivation for nurses and midwives. Interpersonal relationships and respect in the workplace are associated with increased work motivation. In Iran, work motivation is influenced by good coworker relations. Support from good colleagues will motivate health workers (Baljoon et al., 2018). A study conducted by Sarwar and Khalid (2015) found that social support positively affects motivation.

\section{d. The Effect of Marital Status on Perceived Financial Compensation}

The results of this study indicated that there was an indirect effect of marital status on the performance of midwives through perceived financial compensation.

In theory, marriage is a condition that separates the two environments, namely home and works. Married women and mothers are associated with housework and childcare while their partners earn money to support the family. They prioritize household chores overwork outside the home. Therefore, marital status results in the possibility of negative performance for women who are married and become mothers, resulting in reduced work results due to work as mothers (Vuong and Sid, 2020).

The connotation of marital status can be directly related to the household, namely a gender system that separates domestic work and work outside the home (Williams and Dempsey, 2014). A study of marriage adjustment and management of women's labor resources with different incomes concluded that most working women can achieve good (very satisfying) relationships in their married life. If the income of working women increases, their marriage adjustment rate increases. As breadwinners, they are also able to manage family finances (Garima and Kiran, 2014).

A study of midwives in Malawi showed that household chores, caring for children and accountability to partners, lack of partner support negatively impact performance and lead to depersonalization and professional disability (Thorsen et al., 2011). Midwives in three different maternity service units in Luanda, Angola, reported that salaries were too low to provide food, clothing and education for their children. They feel that their wages are not sufficient to support themselves and their children (Filby et al., 2016).

A study conducted by Jagsi et al. (2013) found that the spouse's occupation could explain about one-third of gender differences in salary that other factors could not explain. Unrecognized influence regarding gender on "family wages" is the underlying mechanism for gender differences in wages, even though women's participation rate in work is very high nationally. Family wages may explain salary inequalities among study subjects. Employers may feel that men supporting the family are 
entitled to higher salaries than women who are not seen as the main breadwinners. Given the large differences in family composition between men and women (i.e., women generally have partners who work full-time, and men do not), salary setting may be influenced by extra assumptions about gender rather than performance. Female workers think that their wages are adequate even though the amount is smaller than male workers because there is a "family wage" received from their spouses (Jagsi et al., 2013).

The results showed that there was a significant difference between marital status and employee performance levels. Employees who are not married can perform better than employees who are married. This is because unmarried employees' commitment to their families and other conditions is much lower compared to employees who are married. Married and unmarried employees are treated and given the same level of work pressure. Married employee performance depends on the employee's ability to handle situations and distraction factors that employees face at work and family life (Padmanabhan and Magesh, 2016).

\section{AUTHOR CONTRIBUTION}

Veterina Rizki Amalia collected research data, formulated research articles, and processed data. Hanung Prasetya played a role in the formulation of the background. Bhisma Murti assisted in formulating research methods and data processing.

\section{CONFLICT OF INTEREST}

There is no conflict of interest in this study.

FUNDING AND SPONSORSHIP

This study used scholarship funds from the Ministry of Health of the Republic of Indonesia.

\section{ACKNOWLEDGEMENT}

The authors would like to express their gratitude to the Community Health Center in Mojokerto and the midwives who were willing to work together to become the respondents.

\section{REFERENCE}

Adam, Widarwaty (2015). Pengaruh pendapatan dan motivasi kerja terhadap kinerja bidan di UPF Kebidanan Rumah Sakit Umum Prof. Dr. H. Aloei Saboe. J Midwifery. 1(1):1-10 Retrieved from: http://r2kn.litbang.kemkes.go.id:808o/handle/123456789/33928 ? show=full.

Agwu MO (2013). Impact of fair reward system on employees job performance in Nigerian Agip Oil Company Limited Port-Harcourt. Br J Educ Soc Behav Sci. 3(1): 47-64.doi.org/10.9734/BJESBS/2013/2529.

Alkasseh A, Kweik D (2019). The effect of socio-demographic factors on quality of midwifery performance as perceived by midwives. Clinics in Mother and Child Health. 16(3): 325. https://www.longdom.org/open-access/the-effect-of-sociodemographic-factors-on-quality-of-midwifery-performance-as-perceived-by-midwives43919.html.

Asamani JA, Amertil NP, Chebere M (2015). The influence of workload levels on performance in a rural hospital. British J Healthcare Manag. 21(12): 577-586. doi:10.12968/bjhc. 2015.21.12.577.

Bahadori M, Babaei M, Mehrabian F (2013). Prioritization of factors influencing job motivation in employees of a military center using analytical hierarchy process (AHP). Ir J Military Medicine. 14(4): 1-9 Retrieved from: 
http://militarymedj.ir/article-1-1028en.pdf.

Baljoon RA, Banjar HE, Banakhar MA (2018). Nurses' work motivation and the factors affecting it: A scoping review. Int J Nurs Clin Pract. 5: 277. doi: https://doi.org/10.15344/23944978/2018/277

Beheshtifar M, Ali-Nezhad H, Nekoie-Moghadam M (2012). Investigation of perceived organizational support on employees' positive attitudes toward work. Interdiscipl J Contemp Res Bus. 2012(4): 432-442. http://dx.doi.org/10.3233/WOR-62327.

Bekru E, Cherie A, Anjulo A (2017). Job satisfaction and determinant factors among midwives working at health facilities in Addis Ababa city, Ethiopia. PLOS ONE. 2017(07): 1-16. doi: 10.1371/journal.pone.0172397.

Bertolino M, Truxillo DM, Fraccaroli F (2013). Age effects on perceived personality and job performance. J Manag Psychol. 28(7/8): 867-885. http://dx.doi.org/10.1108/JMP-07-20130222.

Bhakshi E, Kalantari R, Salimi N (2017). Assessment of job performance and its determinants in healthcare workers in Islamabad-e Gahrb City based on ACHIVE Model in 2016. Arak Med Univ J. 20(11): 1-9. Retrieved from: www.amuj.arakmu.ac.ir.

Bhatnagar A, Gupta S, Alonge O, George AS (2017). Primary health care workers' views of motivating factors at individual, community and organizational levels: a qualitative study from Nasarawa and Ondo states, Nigeria. Int $\mathrm{J}$ Health Plann Manage. 32(2): 217-233. https://doi.org/10.1002/hpm.2342.

Cahyandaru Z, Tamtomo D, Soemanto RB (2019). Linear regression analysis on factors affecting health surveillance personnel performance in early detection of preeclampsia in Semarang, Central Java. J Health Policy Manage. 4(1): 13-22. https://doi.org/10.26911/thejhpm. 2019.04.01.02.

D'Ambruoso L, Byass P, Qomariyah SN (2010). Maybe it was her fate and maybe she ran out of blood: Final caregivers' perspectives on access to care in obstetric emergencies in rural. J Biosoc Sci. 42(02): 213-241. doi:10$.1017 /$ So021932009990496.

Dinas Kesehatan ProvinsiJawa Timur (2017). Profil kesehatan Jawa Timur 2017. Dinkes Prov Jatim: Surabaya.

Ensor T, Quayyum Z, Nadjib M, Sucahya P (2008). Level and determinants of incentives for village midwives in Indonesia. Health Policy and Plan. 24(1): 26-35 doi:10.1093/heapol/czn040.

Fan J, Smith AP (2017). The impact of workload and fatigue on performance. Human Mental Workload: Models and Applications. 2017(726): 90-105. doi:10.1007/978-3-319-61061-0_6.

Fernet C, Trépanier SG, Austin S, Gagné M, Forest J, et al. (2015). Transformational leadership and optimal functioning at work: On the mediating role of employees' perceived job characteristics and motivation. Work \& Stress. 29: 11-31 https://doi.org/10.1080/ 02678373.2014.1003998.

Filby Alex, McConville F, Portela A (2016). What prevents quality midwifery care? A systematic mapping of barriers in low and middle income countries from the provider perspective. PLoS ONE. 11(5): 1-20. doi:10.1371/journal.pone.0153391.

Galletta M, Portoghese I, Pili S, Piazza MF, Campagna M (2016). The effect of work motivation on a sample of nurses in an Italian healthcare setting. 
Work. 54(2): 451-460. doi: 10.3233/WOR-162327.

Garima M, Kiran (2014). Impact of marital status on mental health of working women. JMSCR. 2(10): 2594-2605. Retrieved from: https://www.researchgate.net/publication/267506019_.

Gedif G, Sisay Y, Alebel A, Belay Y (2018). Level of job satisfaction and associated factors among health care professionals working at University of Gondar Referral Hospital, Northwest Ethiopia: A cross-sectional study. BMC Res Notes. 11(824): 1-7. doi: 10.1186/s13104-018-3918-0.

Eka GT, Tamtomo DG, Murti M (2018). Determinants of midwife performance on antenatal care in Surakarta and Karanganyar, Central Java. J Health Policy Manage. 3(1): 11-19 https://doi.org/10.26911/thejhpm.2018.03.01.02.

Hammami A, Moldovan R, Peltier E (2020). Salary perception and career prospects in audit firms. Manag. Auditing J. 35(6): 759-793. https://doi.org/10.1108/MAJ-11-2019-2475.

Hee OC, Kamaludin NHB, Lim Le Ping (2016). Motivation and Job Performance among Nurses in the Private Hospitals in Malaysia. Int $\mathrm{J}$ Caring Sci. 9(1): 342-347 Retrieved from: http://www.internationaljournalofcar ingsciences.org/docs/33_Hee_special -9_1.pdf.

Heijden BVD, Kummerling A, Kovarova M, Behar ME, Schoot EVD, Hasselhorn $\mathrm{H}$ (2010). The impact of social support upon intention to leave among female Nurses in Europe: Secondary analysis of data from the NEXT survey. Int $\mathrm{J}$ Nurs Stud. 47(4):434-45. doi: 10.1016/j.ijnurstu.2009.10.004.
Jagsi R, Griffith K, Stewart A, Sambuco D, DeCastro R, et al. (2013). Gender differences in salary in a recent cohort of early-career physician-researchers. Acad Med. 88(11): 1-21. doi:10.1097/ACM.obo13e3182a71519.

Jayanti ND, Tamtomo DG, Sulaeman ES (2017). Path analysis on the effects of motivation and other factors on midwives performance of preeclampsia management in Malang, East Java. J Health Policy Manage. 2(2): 137-146 https://doi.org/10.26911/thejhpm.2017.02.02.05.

Kalhor M, Samieerad F, Garshasbi M, Mafi M, Ranjkesh F (2018). Predictors of quality of work life and job performance in clinical staff in Qazvin, Iran. Int J Epidemiol Res. 5(3):86-91. doi: 10.15171/ijer.2018.19.

Khosravy S, Babaey F, Abedi P, Kalahroodi ZM, Hajimirzaie SS (2020). Strategies to improve the quality of midwifery care and developing midwife-centered care in Iran: Analyzing the attitudes of midwifery experts. J Health Econ. 9(08): 1-20 DOI: https://doi.org/10.21203/rs.3.rs-68394/v1.

Kooji D, Guest D, Clinton M, Knight T, Jansen P, et al. (2013). How the impact of HR practices on employee wellbeing and performance changes with age. Hum Resour Manag J. 23(1): 18-35 doi: 10.1111/1748-8583.12000 .

Negarandeh R, Dehgan-Nayri N, Ghasemi E (2015). Motivating factors among Iranian nurses. Iran J Nurs Midwifery Res. 20(4): 436-41. DOI: 10.4103/1735-9066. 161011.

Ogunleye AJ, Osekita DA (2016). Effect of job status, gender, and employees' achievement motivation behavior on work performance: A case study of selected local government employees 
in Ekiti State, Nigeria. Eur Sci J. 12(26):235-248. doi: 10.19044/esj.2016.v12n26p235.

Padmanabhan L, Magesh R (2016). Difference between employees marital status and performance level in it industry. IJIR. 2(6): 1173-1176. Retrieved from: http://www.onlinejournal.in/IJIRV2I6/221.pdf.

Pour AY, Nekoei MH, Torki S (2016). The relationship between quality of work life and performance of railway headquarter employees in Hormozgan province. Glob J Sci Res. 4(4):63-68. Retrieved from: www.gjsr.blue-ap.org

Rahmadani LN, Budihastuti UR, Pamungkasari EP (2019). Does health center have contextual effect on midwife performance? Multilevel Analysis Evidence from East Kalimantan, Indonesia. J Health Policy Manage. 4(3): 150-16o. https://doi.org/10.26911/thejhpm.2019.04.03.01.

Rouleau D, Fournier P, Philibert A, Mbengue B, Dumont A (2012). The effects of midwives' job satisfaction on burnout, intention to quit and turnover: a longitudinal study in Senegal. Hum Resour Health. 10(9): 1-14. doi: 10.1186/1478-4491-10-9.

Sarwar A, Khalid S (2015). Perceived social support and work motivation of day and night shift nurses. Pak Armed Forces Med J. 65(2): 257-61 Retrieved from: https://www.pafmj.org/index.$\mathrm{php} / \mathrm{PAFMJ} /$ article/view/844.

Shooshtarian Z, Ameli F, Lari MA (2013). The effect of labor's emotional intelligence on their job satisfaction, job performance and commitment. IJMS.
6(1): 27-43. Retrieved from: https://www.sid.ir/en/Journal/ViewPaper.aspx?ID=354937.

Stryzhak O (2020). The relationship between education, income, economic freedom and happiness. The International Conference on History, Theory and Methodology of Learning (ICHTML 2020). 75(03004): 1-6. https://doi.org/10.1051/shsconf/20207503004.

SGDs. Tujuan ketiga. Retrieved from: https://www.sdg2030indonesia.org/.

Thorsen VC, Teten Tharp AL, Meguid T (2011). High rates of burnout among maternal health staff at a referral hospital in Malawi. BMC Nursing. 10(9): 1-7. doi: 10.1186/1472-6955-10-9.

Toode K, Routasalo P, Helminen M, Suominen T (2015). Hospital nurses' work motivation. Scand J Caring Sci. 29(2): 248-57. doi: 10.1111/scs.12155.

Vuong BN, Sid S (2020). The impact of human resource management practices on employee engagement and moderating role of gender and marital status: An evidence from the Vietnamese banking industry. Manag. Sci. Letters 10(7): 1633-1648. doi: 10.5267/j.msl.2019.12.003.

Weyh C, Pilat C, Frech T, Kruger K, Reichel $\mathrm{T}$, Mooren $\mathrm{F}$ (2020). Exercise training reduces workload, improves physical performance, and promotes overall health in welders. J Occup Health. 3(26): 1-11. https://doi.org/10.1002/1348-9585.12122.

Williams JC, Dempsey R (2014). What works for women at work. New York: New York University Press. 